\title{
Analisis Penggunaan Kaidah Al-hājah Qad Tunazzalu Manzilah al-D arūrah Dalam Fatwa Dewan Syariah Majelis Ulama Indonesia
}

\author{
Imam Mustofa \\ Intitut Agama Islam Negeri Metro \\ mustofaiain@metrouniv.ac.id
}

Abstrak: The Fiqh Legal Maxim (al-qawā'id al-fiqhiyyah) or principles have an important role in facilitating the understanding of Islamic law. This paper reviewed and analyzed the intensity and accuracy of the use of legal maxim in the fatwa of the Sharia Council Indonesian Ulama Council (DSN-MUI). The focus of the study in this paper was the principle of al-ahājah qad tunazzalu manzilah al-darürah, which is contained in the book collection of DSNMUI fatwas on Islamic finance from 2000 to 2012. The study in this paper was based on literature data analyzed using content analysis method inductively. The analysis includes fatwa mapping, the intensity of the use figh legal maxim, and the accuracy of the use of principle. This study concluded that the fatwa of the Indonesian Sharia Council-Ulama Council regarding sharia finance from 2000 to 2012 frequently used the fiqh legal maxim of al-hājah qad tunazzalu manzilah al-darūrah āmmah kanat aw khāsșah as a foundation. The high intensity of the use of this principle in the fatwa related to Islamic finance showed that this principle was considered vital in responding to community problems related to Islamic finance. The use of this principle by the DSN-MUI as the basis for establishing law in the fatwa related to the products and services of Islamic Financial Institutions (LKS) needed by the society is appropriate and can answer the problems of economic law in Indonesia

Abstrak: Kaidah fiqih mempunyai peran penting dalam rangka mempermudah pemahaman tentang hukum Islam. Tulisan ini mengkaji dan menganalisa intensitas dan ketepatan penggunaan 
kaidah fiqih dalam fatwa Dewan Syariah- Majelis Ulama Indonesia (DSN-MUI). Fokus kajian dalam tulisan ini adalah kaidah al-hājah qad tunazzalu manzilah al-darurah, yang terdapat dalam buku kumpulan fatwa DSN-MUI tentang keuangan Syariah dari tahun 2000 sampai dengan tahun 2012. Kajian dalam tulisan ini berdasarkan data literatur yang dianalisa dengan mempergunakan metode analisis isi secara induktif. Anaisa meliputi pemetaan fatwa, intensitas penggunaan kaidah, dan ketepatan penggunaan kaidah. Kajian ini menyimpulkan bahwa fatwa Dewan Syariah-Majelis Ulama Indonesia tetang keuangan syariah dari tahun 2000-tahun 2012 banyak yang menggunakan kaidah al-hājah qad tunazzalu manzilah al-ḍarūrah āmmah kanat aw khāșsah sebagai landasan. Tingginya intensitas penggunaan kaidah ini dalam fatwa yang terkait dengan keuangan syariah menunjukkan bahwa kaidah ini cukup diperhitungkan dalam menjawab problem masyarakat terkait dengan keuangan syariah. Penggunaan kaidah ini oleh DSN-MUI sebagai dasar penetapan hukum dalam fatwa terkait produk dan layanan Lembaga Keuangan Syariah (LKS) yang dibutuhkan oleh masyarakat sudah tepat dan dapat menjawab problem hukum ekonomi di Indonesia

Kata kunci: Fatwa, intensitas, kaidah fiqih, ḍarūrah, dan ḥājah.

\section{A. Pendahuluan}

Sejak abad ke 19, fatwa telah menjadi bagian integral dari lembaga hukum. ${ }^{1}$ Sampai saat ini, sebagian negara muslim seperti Mesir, Malaysia, Brunai Darussalam, masih memposisikan fatwa menjadi bagian dari hukum positif. ${ }^{2}$ Di Indonesia, fatwa mempunyai posisi dan peran signifikan sebagai landasan dan dalil hukum di pengadilan, khususnya di Pengadilan Agama. Majelis Ulama Indonesia mejadi salah satu rujukan umat Islam Indonesia dalam menjawab berbagai permasalahan sosial keagamaan. Permasalahan

1 Achmad Kemal Riza, "Contemporary Fatawa of Nahdlatul Ulama Between Observing the Madhhab and Adapting the Context," JOURNAL OF INDONESIAN ISLAM, 05, No. 01 (Juni 2011): 39-40 Lebih lanjut baca Muhammad Khalid Masud, Brinkley Messick, dan David. S Powers, ed., Islamic Legal Interpretation: Muftis and Their Fatwas (London: Hardvard University Press, 1996).

${ }^{2}$ Isa Ansori, "Kedudukan Fatwa di Beberapa Negara Muslim (Malaysia, Brunei Darussalam dan Mesir)," Analisis: Jurnal Studi Keislaman 17, no. 1 (28 November 2017): 137-66, doi:10.24042/ajsk.v17i1.1790. 
yang juga banyak merujuk kepada fatwa MUI, khususnya Dewan Syariah Nasional-MUI adalah permasalahan ekonomi syariah.

MUI melalui DSN telah menetapkan standar hukum syariah dalam operasional lembaga keuangan. ${ }^{3}$ Berbagai fatwa yang dikeluarkan MUI mendorong perkembangan tersbut. Fatwa MUI melalui Dewan Pengawas Syariah juga berperan signifikan dalam penyelesaian sengketa bisnis syariah, baik pada lembaga makro maupun mikro syariah. ${ }^{4}$ Fatwa DSN-MUI menjadi rujukan bagi regulasi yang dikeluarkan oleh Bank Indonesia, baik terkait substansi, materi maupun praktik ekonomi syariah dalam lembaga keuangan syariah. ${ }^{5}$ Fatwa MUI menjadi acuan untuk mengadili sengketa ekonomi syariah. ${ }^{6}$ MUI telah mampu menjadi institusi Muslim paling otoritatif di Indonesia di bidang produksi fatwa. Peran ini telah terbukti selama sepuluh tahun terakhir. Selain itu, selama dekade ini, fatwa MUI telah berhasil menarik perhatian Muslim Indonesia dan non-Muslim, mendorong mereka untuk berbicara tentang interpretasi institusi ini baik secara positif maupun negatif. ${ }^{7}$

\footnotetext{
${ }^{3}$ Nur Hidayah, "Fatwa-fatwa Dewan Syariah Nasional Atas Aspek Hukum Islam Perbankan Syariah di Indonesia," AL- 'ADALAH, X, no. 1 (Januari 2011): 15.

4 Jaih Mubarok dan Hasanudin, "Dinamika fatwa produk keuangan syariah," Ijtihad, Jurnal Wacana Hukum Islam dan Kemanusiaan 13, no. 1 (1 Juni 2013): 1 . Menurut UU Nomor 3 tahun 2006 jo Pasal 55 Ayat (1) dan (2) UU Nomor 21 tahun 2008 tentang Perbankan Syari'ah penyelesaian sengketa ekonomi syariah dapat diselesaikan melalui Pengadilan Agama, Pengadilan Negeri, Badan arbritase (Badan Arbritase Syariah Nasional) yang menjalankan hukum materiil berdasarkan syariah. Berdasarkan hal ini, setidaknya ada dua cara penyelesaian yang dapat untuk menyelesaiakan sengketa dalam Islam, termasuk perkara bisnis syariah, yaitu melalui peradilan dan arbitrase. (Rangkuti, "Sistem Penyelesaian Sengketa Ekonomi Islam: Instrumen Penting bagi Konsep Ekonomi Islam Mendatang," 1432; dan Abdul Hamdi, “Aplikasi Teori Mashlahah [Maslahat] Najm AL-Dîn AL-Thûfî dalam Penyelesaian Sengketa Perjanjian Bisnis di Bank Syariah,” AL-“ADALAH XII, no. 4 [Desember 2015]: 730).

5 Maskufa Maskufa, "Penyelesaian Sengketa Perjanjian Syariah pada Lembaga Keuangan Syariah," Al-Iqtishad Journal of Islamic Economics 5, no. 1 (Januari 2013): 127.

${ }^{6}$ Erie Hariyanto, "Penyelesaian Sengketa Ekonomi Syariah di Indonesia," Iqtishadia al-Ihkâm 1, no. 1 (Jun i 201 4): 45 Baca juga; Atang Abd Hakim dan Sofyan al-Hakim, "Kerangka Penyelesaian Sengketa Bisnis Syariah," AT TARADHI Jurnal Studi Ekonomi 6, no. 1 (2015): 47.

${ }^{7}$ Syafiq Hasyim, "The Council of Indonesian Ulama (Majelis Ulama Indonesia, MUI) and Religious Freedom," (Irasec's Discussion Papers, 12 Desember 2011), 8.
} 
Dewan Syariah Nasional-Majelis Ulama Indonesia (DSNMUI) dalam menetapkan fatwa melalui beberapa proses dan menggunakan dalil dan landasan hukum yang berlapis. Secara umum, dalil dan landasan hukum yang digunakan tersebut secara hirarkis adalah 1) al-Quran, 2) al-Sunnah, 3) Ijma' ulama, 4) Kaidah fiqih, 4) Pendapat ulama madzhab dan ulama kontemporer. Hirarki ini menunjukkan bahwa kaidah fiqih mempunyai posisi yang strategis dalam penetapan fatwa DSN terkait keuangan syariah. ${ }^{8}$ Kaidah fiqih menjadi pertimbangan penting dalam penetapan fatwa.

Kaidah fiqih (qawā'id al-fiqhiyyah) adalah abstraksi teoritis, biasanya dalam bentuk pernyataan singkat, yang ekspresif, umumnya tersusun dalam beberapa kata, tentang tujuan dan sasaran syariah. Ia berupa pernyataan prinsip yang berasal dari pembacaan terperinci tentang aturan fiqh pada berbagai tema. ${ }^{9}$ Kaidah fiqih biasanya tersusun dari beberapa kata, tentang tujuan dan sasaran Sharī'ah. ${ }^{10}$ Kaidah fiqih sangat banyak, sehingga banyak ulama (ilmuwan) memperlakukan kaidah-kaidah tersebut sebagai cabang dari literatur maqasid (tujuan dan tujuan). Saat ini kaidah fiqih menjadi disiplin ilmu tersendiri yang diajarkan di perguruan tinggi Islam. ${ }^{11}$

Kaidah fiqih mempunyai peran penting dalam rangka mempermudah pemahaman tentang hukum Islam, di mana berbagai hukum cabang yang banyak tersusun menjadi satu kaidah. ${ }^{12}$ Karena, pada dasarnya kaidah merupakan prinsip umum yang diberlakukan pada berbagai kasus. ${ }^{13}$ Kaidah fiqih digunakan oleh para ulama kontemporer untuk melegitimasi pendapat mereka (keputusan hukum

8 Aidil Novia, "Kontribusi Fiqh Legal Maxim dalam Fatwa-Fatwa Ekonomi Syariah Dewan Syariah Nasional Majelis Ulama Indonesia (DSN-MUI)," TSAQAFAH 12, no. 1 (14 Mei 2016): 79-104, doi:10.21111/tsaqafah.v12i1.369.

${ }^{9}$ Mohammad Hashim Kamali, "Qawa 'id Al-Fiqh: The legal maxims of Islamic law," The Association of Muslim Lawyers, 2008, 1.

${ }^{10}$ Ibid, 34 baca juga; Buerhan Saiti dan Adam Abdullah, "The Legal Maxims of Islamic Law (Excluding Five Leading Legal Maxims) and Their Applications in Islamic Finance (1)," t.t., 140.

${ }^{11}$ Mohammad Hashim Kamali, "Legal Maxims and Other Genres of Literature in Islamic Jurisprudence," Arab Law Quarterly 20, no. 1 (2006): 78.

12 Syamsul Hilal, "Qawâ‘'Id Fiqhiyyah Furū'Iyyah Sebagai Sumber Hukum Islam,” $A L$-'ADALAH 11, no. 2 (28 Februari 2013): 145.

${ }^{13}$ Khadiga Musa, "Legal Maxims as a Genre of Islamic Law Origins, Development and Significance of Al-Qawā'id al-Fiqhiyya," Islamic Law and Society 21 (2014): 329. 
yang lebih disukai) mengenai isu-isu spesifik. Contohnya, ketika membahas kontrak ta'min (asuransi), ahli hukum yang menganggap kontrak tersebut berlaku sesuai dengan kaidah darurah (kebutuhan) dan $\bar{a} d a h$ (tradisi). ${ }^{14}$

Tulisan ini mengkaji dan menganalisa intensitas dan ketepatan penggunaan kaidah fiqih dalam fatwa MUI. Fokus kajian dalam tulisan ini adalah kaidah al-hājah qad tunazzalu manzilah aldarurah, yang terdapat dalam buku kumpulan fatwa DSN-MUI tentang keuangan Syariah dari tahum 2000 sampai dengan tahun 2012.

Kajian tentang kaidah fiqih dalam fatwa yang terkait dengan masalah keuangan syariah sudah dilakukan beberapa ilmuan. Pertama, Penelitian Aidil Novia "Kontribusi Fiqh Legal Maxim dalam Fatwa-Fatwa Ekonomi Syariah Dewan Syariah Nasional Majelis Ulama Indonesia (DSN-MUI)". Novia menyimpulkan dalam peneltian ini bahwa menunjukkan bahwa 97\% fatwa DSN yang terkait dengan keuangan Syariah menggunakan kaidah fiqih sebagi landasan. Namun demikian, penggunaan kaidah fiqih tersebut menurut Novia belum maksimal. sementara banyak ulama mengatakan bahwa kaidah memiliki kaitan yang sangat erat dengan maqasyid Syari'ah yang menjadi inti dari hukum ekonomi dan keuangan syariah. Sehingga dengan demikian, dalam menghadapi perkembangan lembaga keuangan syariah yang begitu cepat, sangatlah penting kehadiran kaidah fiqih ini apabila dikaitkan dengan fatwa akan diterbitkan ${ }^{15}$. Penelitian Novia ini baru sebatas mengungkap penggunaan kaidah fiqih dalam fatwa DSN-MUI. Ia tidak sampai mengkaji bagaimana kaidah dan fatwa tersebut berperan dalam penyelesaian sengketa bisnis syariah di Indonesia. Ia juga tidak mengungkap bagaimana pengaruh kaidah fiqih dalam penyelesaian sengketa bisnis syariah. ${ }^{16}$ Penelitian ini bersifat umum, terkait dengan penggunaan semua kaidah fiqih yang terkait dengan mu'amalah.

${ }^{14}$ Fawzy Shaban Elgariani, “Al-Qawā’id Al-Fiqhiyyah (Islamic Legal Maxims): Concept, Functions, History, Classifications and Application to Contemporary Medical Issues,” 10 Februari 2012, 111.

${ }^{15}$ Novia, "Kontribusi Fiqh Legal Maxim dalam Fatwa-Fatwa Ekonomi Syariah Dewan Syariah Nasional Majelis Ulama Indonesia (DSN-MUI),” 79-104.

${ }^{16}$ Ibid. 
Kedua, penelitian Muntakhabul Haq yang berjudul "Shari'ah Decisions on Financial Matters and the Application of Islamic Legal Maxims (Al-Qawa'id Al-Kuliyyah): A Comparative Analysis between the modern and Classical Applications". Studi ini menemukan bahwa Kaidah fiqih yang banyak digunakan dalam fatwa terkait dengan masalah keuangan syariah di Malaysia adalah kaidah "al-Masyaqqatu Tajlibut Taisir" dan "al-Dhararu Yuzal." 17

Ketiga, penelitian Buerhan Saiti dan Adam Abdullah, yang berjudul The Legal Maxims of Islamic Law (Excluding Five Leading Legal Maxims) and Their Applications in Islamic Finance. Penelitian ini menyimpulkan bahwa kaidah fiqih, yang terkait dengan keuangan dan perbankan syariah, makna umum dan aplikasinya di industri ini. ${ }^{18}$

Tulisan ini merupakan kajian kualitatif. Data primer berupa dokumen fatwa DSN-MUI tentang keuangan Syariah dari tahum 2000 sampai dengan tahun 2012. Sementara data skunder skunder yaitu artikel, buku atau kajian yang terkait dengan kaidah fiqih, fatwa MUI dan penyelesaian sengketa bisnis syariah melalui arbitrase. Data yang telah terkumpul dianalisis dengan metode content analisys. ${ }^{19}$ Analisis dilakukan dengan langkah-langkah sebagai berikut peratama, memetakan fatwa DSN-MUI yang menggunakan kaidah fiqih di dalamnya. Kedua, analisis penggunaan kaidah al-häjah qad tunazzalu manzilah al-darurah dalam fatwa DSN-MUI dalam kumpulan fatwa tentang Keuangan Syariah. Ketiga, analisa ketepatan penggunaan kadah tersebut dalam fatwa terkait Keuangan Syariah. Sebagai penelitian kualitatif, ${ }^{20}$ kajian ini menggunakan analisis induktif. Dalam hal ini akan dibuat kategori-kategori berbagai tema

${ }^{17}$ Marifatul Haq Yasini, Shari'ah Decisions on Financial Matters and the Application of Islamic Legal Maxims (Al-Qawa'id Al-Kuliyyah): A Comparative Analysis Between the Modern and Classical Applications, 2015.

${ }^{18}$ Buerhan Saiti dan Adam Abdullah, "The Legal Maxims of Islamic Law (Excluding Five Leading Legal Maxims) and Their Applications in Islamic Finance," 2016.

${ }^{19}$ Metode konten analisis dilakukan dengan teknik membuat inferensiinferensi yang dapat ditiru dan sahih data dengan memperhatikan konteksnya. lihat Klaus Krippendorff, Content Analysis; an Indtroduction to Its Methodology (London: Sage Publication, 2004).

${ }^{20}$ Norman K. Denzin dan Yvonna S. Lincoln, Hand Book of Qualitative Research (Yogyakarta: Pustaka Pelajar, 2009), 272. 
dan pola-pola tertentu dari data. Kategori-kategori tersebut dirumuskan berdasarkan catatan terhadap data yang ada.

Kajian ini memberikan kontribusi bagi kajian hukum Islam, khususnya hukum ekonomi syariah di Indoensia. Kajian mengenai kaidah dan fatwa dalam memperkuat perannya dalam penyelesaian berbagai masalah sosial keagamaan. Kajian ini akan memberikan kontribusi tentang penguatan peran kaidah dan fatwa dalam kehidupan sosial, khususnya bagi umat Islam. Kaidah fiqih sampai saat ini telah berperan signifikan dalam penemuan dan penentuan hukum Islam.

\section{B. Eksistensi Kaidah Fiqih Dan Penggunaannya Dalam Fatwa DSN-MUI}

Kaidah fiqih adalah pernyataan ringkas yang mencakup seluruh komponen yang berada di bawahnya atas dasar kesamaan alasan atau illah, dimana hukumnya akan selalu sama selama ada kesamaan kondisi. ${ }^{21}$ Kaidah fiqih mempunyai kekuatan hukum untuk berhujjah, baik mempunyai landasan secara langsung dengan nașs seperti kaidah al-umūru bimaqāṣidihā, maupun kaidah yang bersumber dari pemikiran deduktif dan tidak langsung bersandar kepada nas. $^{22}$

Beberapa ilmuwan berpendapat bahwa kaidah fiqih bahkan diprioritaskan dari qiyas. Menurut mereka, qiyas awalnya adalah untuk melampirkan satu isu (yang tidak memiliki ketetapan hukum yang jelas) terhadap isu tunggal lainnya (yang status hukumnya telah ditentukan oleh Al Qur'an, Sunnah, atau dalil-dalil di bawahnya). Sedangkan sifat kaidah fiqih melampirkan satu isu ke beberapa isu lainnya, yang sudah memiliki status hukum. Ulama kontemporer memanfaatkan kaidah fiqih dalam usaha untuk menentukan keputusan hukum untuk berbagai isu baru. Hal ini muncul dalam konteks meningkatnya kajian terhdap kaidah fiqih di era sekarang. ${ }^{23}$

${ }^{21}$ Fatḥ̄ Muhammad Abu al-Warad, Atsaru Qā'idah al-hājah Tunazzilu Manzilah al-Darūrah fì Isqāti Ú U'Uqūbah al-Sirqah fí Fiqh al-Jināi al- Muāṣir (Riyaḍ: Markaz al-Tamyīz al-Baḥtsī fī Fiq al-Qaḍāyā al-Mu'āṣirah, 2010), 1171.

${ }^{22}$ ÍMuḥammād Alī Jum'ah, al-Qawāid al-Fiqhiyyah al-Muyassarah (Kairo: Tp., 2006), 10. $107-11$.

${ }^{23}$ Baca Elgariani, "Al-Qawā’id Al-Fiqhiyyah (Islamic Legal Maxims)," 
Dengan merujuk dan menjadikan kaidah fiqih sebagai landasan dalam penetapan hokum atas suatu kasus yang tidak ada nașs-nya, maka masyarakat dapat bermu'amalah sesuai dengan prinsip syariah, atau setidaknya mendekati dengan ketentuan dan prinsip syariah. ${ }^{24}$

Kaidah fiqih sangat berperan penting dalam ijtihad untuk menemukan hukum Islam. Bahkan ia menjadi disiplin ilmu tersendiri yang terkait dengan hukum Islam. ${ }^{25}$ Setidaknya ada tiga poin terkait urgensi kaidah fiqih dalam penemuan hukum Islam. 1) kaidah fiqih mempunyai kedudukan istimewa dalam khazanah keilmuan Islam karena kepakaran seorang faqīh sangat terkait erat dengan penguasaan kaidah fiqih. 2) kaidah fiqih dapat menjadi landasan berfatwa. 3), Kaidah fiqih menjadikan ilmu fiqih lebih teratur sehingga mempermudah seseorang untuk mengidentifkasi fiqih yang jumlahnya sangat banyak.$^{26}$

Di era sekarang, kaidah fiqih juga digunakan untuk mencari solusi berbagai masalah baru dalam bidang hukum Islam. Dengan demikian, para ahli hukum saat ini menuntut agar maqasyid dan qawa'id dapat digunakan sebagaimana usulul fiqh yang belum merespons secara memadai terhadap tuntutan pembaharuan dan ijtihad di era sekarang. ${ }^{27}$ Kaidah fiqih ini digunakan oleh para ahli hukum kontemporer untuk mendukung ikhtiyarat fiqhiyyah mereka (keputusan hukum yang lebih disukai) mengenai hal-hal tertentu. ${ }^{28}$ Kaidah fiqih dapat menjadi referensi utama bagi mufti untuk

${ }^{24}$ Muhammad Șidqī bin Aḥmad al-Burnū, Majmū'ah al-Qawā'id alFiqhiyyah: Jam'wa Tartīb wa Bayān (Riyaḍ: Maktabah al-Taubah, 1997), 44.

${ }^{25}$ Luqman Zakariyah, "Legal Maxims and Islamic Financial Transactions: A Case Study of Mortgage Contracts and the Dilemma for Muslims in Britain," Arab Law Quarterly 26, no. 3 (1 Januari 2012): 265-66, doi:10.1163/1573025512341240 .

${ }^{26}$ Imam Abul Abbas Ahmad bin Idris Ash-Shonhaji Al-Qorofi, Al-Furuq / Anwarul Buruq Fi Anwa'il Furuq (Beirut - Lebanon: Darul Kutub Al-Ilmiyah, 1998), 3.

${ }^{27}$ Pada Abad VIII Hijriyah, kajian kaidah fikih mulai tumbuh. Pada abad ini para ahli hukum Islam mulai banyak yang konsen mengkaji dan menjadikannya komponen penting dalam penyelesaian masalah-masalah hukum Islam (Khaleel Mohammaed, “The Islamic Law Maxims," slamicStudies 44, no. 2 [2005]: 197200).

${ }^{28}$ Shahzadi Pakeeza, "Role of Al- Qawāi'd Al-Fiqhiyya (Islamic Legal Maxims) in Ijtihād” 5, no. 2 (2014): 42. 
mengeluarkan sebuah fatwa tentang kasus tertentu, selama tidak ada nash atau dalil yang terkait dengan hal tersebut. ${ }^{29}$

Berdasarkan studi litaratur terhadap kumpulan fatwa MUI tentang keuangan syariah, pada setiap fatwa hampir selalu mencantumkan kaidah fiqih sebagai landasan. Namun demikian, kaidah yang digunakan hampir selalu sama, apapun fatwa keuangan syariah yang ditetapkan. Padahal apabila diperhatikan dalam literatur fiqih, sangat banyak kaidah fiqih yang berkaitan dengan ekonomi dan keuangan syariah, atau bahkan apabila dibandingkan karya terbaik yang pernah ada, yaitu kitab Majallah al-Ahkam al-'Adliyyah, yang berisi 1851 pasal (fatwa) dengan mempergunakan 99 kaidah fiqih. ${ }^{30}$ Hal ini perlu disikapi dengan melakukan kajian yang mendalam tentang penggunaan kaidah fiqih tersebut dalam fatwa MUI, khususnya yang terkait dengan keuangan syariah. Lebih jauh, diperlukan juga kajian mengenai imlikasi penggunaan kaidah tersebut dalam penyelesaian sengketa bisnis syariah melalui jalur non-litigasi arbitrase.

Beradasarkan temuan dalam buku kumpulan fatwa DSN-MUI tentang keuangan Syariah dari tahun 2000 sampai dengan tahun 2012, bisa dikatakan bahwa $97 \%$ fatwa tersebut menggunakan kaidah fiikih. Buku tersebut memuat berbagai fatwa terkait dengan keuangan syariah yang jumlahnya mencapai 87 fatwa. Dari jumlah tersebut hanya 2 fatwa yang di dalamnya tidak terdapat kaidah fiqih, yaitu fatwa Nomor: 24/DSN-MUI/III/2002 tentang safe doposit box dan fatwa nomor Nomor: 28/DSN-MUI/III/2002 tentang jual beli mata uang. ${ }^{31}$

Ada sekitar 37 kaidah yang digunakan dalam fatwa DSNMUI yang tersebar ke dalam 87 fatwa. Dari jumlah kaidah tersebut, ada tiga kaidah yang paling sering digunakan. Bila diurutkan dalam lima besar kaidah yang paling sering digunakan dalam fatwa DSNMUI tentang Keuangan syariah, maka dapat dipaparkan dalam table berikut:

29 'Alī Aḥmad al-Nadwī, al-Qawā'id al-Fiqhiyyah (Damaskus: Dār alQolam, 1998), 331.

${ }^{30}$ Novia, "Kontribusi Fiqh Legal Maxim dalam Fatwa-Fatwa Ekonomi Syariah Dewan Syariah Nasional Majelis Ulama Indonesia (DSN-MUI)," 84.

${ }^{31}$ Baca Hijrah Saputra, Andriansyah Syihabuddin, dan Adhika Prasetya, ed., Himpunan Fatwa Keuangan Syariah Dewan Syariah Nasional MUI (Jakarta: Erlangga, 2014). 
Tabel. 1

Kaidah yang digunakan dalam Fatwa DSN-MUI

\begin{tabular}{|c|c|c|c|}
\hline No & Kaidah & $\begin{array}{c}\text { Jumlah } \\
\text { Penggunaan }\end{array}$ & $\begin{array}{c}\text { Peringkat Intensitas } \\
\text { Penggunaan }\end{array}$ \\
\hline 1. & 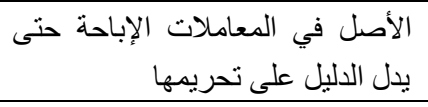 & 84 & I \\
\hline 2. & الحاجة قد تنزل منزلة الضرروة & 23 & II \\
\hline 3. & الضرر يزال & 19 & III \\
\hline 4. & المشقة تجلب التيسير & 19 & IV \\
\hline 5. & اينما وجدت المصلحة فتم حكم الله & 12 & $\mathrm{~V}$ \\
\hline
\end{tabular}

Table di atas dengan jelas memperlihatkan bahwa kaidah alașlu fì al- mu'āmalāt al-ibāḥah ḥatta yadulla al-dalīlu 'alā taḥīmiha merupakan kaidah yang paling sering digunakan dalam fatwa DSNMUI adalah kaidah yaitu digunakan sebanyak 84 kali dari 87 fatwa, artinya, hanya 3 fatwa yang tidak menggunakan kaidah tersebut. Itu pun karena dalam tiga fatwa tersebut memang tidak menggunakan satu kaidah pun sebagai landasan dan pertimbangan.

\section{Penggunaan Kaidah Al-Häjah Qad Tunazzalu Manzilah Al- Darurah Dalam Fatwa DSN-MUI}

Penulis memilih kaidah al-hājah qad tunazzalu manzilah aldarurah, karena dalam kaidah ini terdapat kata hajjah (kebutuhan) yang terikat dengan batasan dan kriteria yang dibuat dan tetapkan oleh ulama. Hampir semua kitab syarah yang menjeaskan kaidah alhājah qad tunazzalu manzilah al-ḍarurah, memberikan kriteria dan batasan mengenai al-hājah (kebutuhan). Sementara kaidah yang paling banyak digunakan yang pertama, yaitu al-așlu fì al-mu'āmalāt al-ibāḥah ḥatta yadulla al-dalīlu 'alā taḥīmiha merupakan kaidah dasar yang pada umumnya sudah menjadi kesepakatan ulama mengenai pemberian ruang yang luas bagi pengembangan praktik mu'amalah.

Kaidah al-hājah qad tunazzalu manzilah al-darurah, menduduki posisi kedua sebagai kaidah yang paling banyak digunakan dalam buku kumpulan fatwa Keuangan Syariah DSNMUI. Kaidah ini digunakan sebanyak 23 kali. Fatwa-fatwa yang 
menggunakan kaidah al-hāja qad tunazzalu manzilah al-ḍarurah secara rinci adalah sebagai berikut:

\section{Tabel 2.}

Tabel Intensitas Penggunaan Kaidah al-hājah qad tunazzalu manzilah al-darurah dalam Buku Kumpulan Fatwa DSN-MUI tentang Keuangan Syariah (2000-2012)

\begin{tabular}{llll}
\hline No & No Fatwa & Subyek & \multicolumn{2}{c}{ Keterangan } \\
\hline 1. & 22/DSN- & Jual Beli & Lembaga Keuangan Syariah (LKS) sebagai \\
& MUI/III/20 & Istishna' & mustașni dari nasabah dapat dapat \\
& 02 & Paralel & memesan kepada pihak ketiga untuk \\
& & memenuhi kebutuhan pesanan nasabah. \\
& & Hanya saja LKS dilarang mengambil \\
& & margin during constructiom (MDC) dari \\
& & nasabah yang memesan barang. Fatwa ini \\
& & tidak merinci jenis dan kriteria obyek \\
& & istișna yang dipesan nasabah. Apakah \\
& & obyek atau komoditas tersebut benar-benar \\
& & menjadi kebutuhan masyarakat secara \\
& & mendesak.
\end{tabular}

\begin{tabular}{lll}
\hline 29/DSN- & Pembiayaan & Fatwa ini melegitimasi tindakan LKS \\
MUI/VI/20 & Pengurusa & untuk mengenakan biaya pengurusan haji \\
02 & Haji & kepada nasabah, karena pengurusan \\
& Lembaga & pembiayaan haki menjadi kebutuhan \\
& Keuangan & masyarakat. pengurusan tersebut dengan \\
& Syariah & menggunakan akad dan prinsip ijarah. \\
& & Lebih dari itu, fatwa ini juga melegitimasi \\
& diperbolehkannya LKS memberikan \\
& talangan pelunasan dana haji nasabah bila \\
& perlukan.
\end{tabular}

\begin{tabular}{lll}
\hline 3. & 30/DSN- & Pembiayaan \\
& MUI/VI/20 & Rekening \\
02 & Koran \\
& Syariah
\end{tabular}

Fatwa ini melegitimasi LKS untuk mengambil upah (ujrah) dari jasa atau fasilitas reking koran dan melegitimasi diperbolehkannya Pembiayaan Rekning Koran Syariah (PRKS) yang dapat pula dilakukan degan wa'd dalam pemberian fasilitas pinjaman (qard). Fatwa ini juga tidak memberikan batasan dan kriteria kebutuhan pinjaman melalui akad (qard) yang diajukan nasabah, apakah kebutuhan primer, skunder atau hanya kebutuhan tersier. 


\begin{tabular}{|c|c|c|c|}
\hline 4. & $\begin{array}{l}31 / \mathrm{DSN}- \\
\mathrm{MUI} / \mathrm{VI} / 20 \\
02\end{array}$ & $\begin{array}{l}\text { Pengalihan } \\
\text { Utang }\end{array}$ & $\begin{array}{l}\text { Fatwa ini melegitimasi LKS untuk } \\
\text { mengambil upah atas pengalihan utang } \\
\text { nasabah kepada Lembaga Keuangan } \\
\text { Konvensional kepada LKS agar } \\
\text { dibayarkan. } \\
\text { melaksanakan kemudian }\end{array}$ \\
\hline 5. & $\begin{array}{l}\text { 34/DSN- } \\
\mathrm{MUI} / \mathrm{XI} / 20 \\
02\end{array}$ & $\begin{array}{l}\text { Letter of } \\
\text { Credit (L/C) } \\
\text { Impor } \\
\text { Syariah }\end{array}$ & $\begin{array}{l}\text { Letter of Credit (L/C) impor syariah adalah } \\
\text { pernyataan akan membayar kepada } \\
\text { eksportir yang diterbitkan oleh bak untuk } \\
\text { kepentingan importir dengan memenuhi } \\
\text { persyaratan tertentu sesuai denganprinsip } \\
\text { syariah. Fatwa ini melgitimasi } \\
\text { diperbolehkannya LKS mengambil } \\
\text { keuntungan dalam bentuk nominal (bukan } \\
\text { persentase) atau upah ujrah dari pelayanan } \\
\text { dan atau jasa yang diberikan kepada } \\
\text { nasabah dengan akad wakălah bil ujrah, } \\
\text { qard, murăbahah, salam, istisnā', } \\
\text { mud̄ärabah, musyārakah atau hawälah. } \\
\text { Penerbitan surat tersebut memang menjadi } \\
\text { kebutuhan mendesak bagi masyarakat, } \\
\text { khususnya pada importir, namun } \\
\text { komoditas yang yang diimpor tidak } \\
\text { ditegaskan dalam fatwa ini, apakah } \\
\text { kebutuhan tersebut memang mendesak } \\
\text { bagi masyarakat atau tidak. }\end{array}$ \\
\hline 6. & $\begin{array}{l}\text { 35/DSN- } \\
\mathrm{MUI} / \mathrm{XI} / 20 \\
02\end{array}$ & $\begin{array}{l}\text { Letter of } \\
\text { Credit (L/C) } \\
\text { Ekspor } \\
\text { Syariah }\end{array}$ & $\begin{array}{l}\text { Letter of Credit (L/C) ekspor syariah } \\
\text { adalah pernyataan akan membayar kepada } \\
\text { eksportir yang diterbitkan oleh bank untuk } \\
\text { perdagangan ekspor dengan memenuhi } \\
\text { persyaratan tertentu sesuai denganprinsip } \\
\text { syariah. Fatwa ini melgitimasi } \\
\text { diperbolehkannya LKS mengambil } \\
\text { keuntungan dalam bentuk nominal (bukan } \\
\text { persentase) atau upah ujrah dari pelayanan } \\
\text { dan atau jasa yang diberikan kepada } \\
\text { nasabah dengan akad wakālah bil ujrah, } \\
\text { qard, mudarabah, musyārakah atau al-bai, } \\
\text { (jual beli). Penerbitan surat tersebut } \\
\text { memang menjadi kebutuhan mendesak } \\
\text { bagi masyarakat, khususnya pada } \\
\text { eksportir, namun komoditas yang yang } \\
\text { diekspor tidak ditegaskan dalam fatwa ini, } \\
\text { apakah kebutuhan tersebut memang }\end{array}$ \\
\hline
\end{tabular}




\begin{tabular}{|c|c|c|c|}
\hline & & & mendesak bagi masyarakat atau tidak. \\
\hline 7. & $\begin{array}{l}\text { 36/DSN- } \\
\text { MUI/X/20 } \\
02\end{array}$ & $\begin{array}{l}\text { Sertifikat } \\
\text { Wadiah } \\
\text { Bank } \\
\text { Indonesia } \\
\text { (SWBI) }\end{array}$ & $\begin{array}{l}\text { Fatwa ini melegitimasi Bank Indonesia } \\
\text { untuk mengeluarkan sertifikat waḍi } a h \\
\text { yang dapat dimanfaatkan Bank Syariah } \\
\text { untuk mengatasi kelebihan likuiditas. } \\
\text { Pengeluaran sertifikat ini memang menjadi } \\
\text { kebutuhan mendesak dalam rangka } \\
\text { menjaga keseimbangan likuiditas. }\end{array}$ \\
\hline 8. & $\begin{array}{l}\text { 42/DSN- } \\
\text { MUI/X/20 } \\
04\end{array}$ & $\begin{array}{l}\text { Syariah } \\
\text { Charge } \\
\text { Card }\end{array}$ & $\begin{array}{l}\text { Fatwa ini melegitimasi diperbolehkannya } \\
\text { LKS untuk mengambil upah ujrah atau fee } \\
\text { terhadap penyediaan jasa atau pelayanan } \\
\text { yang diberikan dalam kartu kredit. Upah } \\
\text { atas fasilitas ini diperbolehan, karena } \\
\text { fasilitas kartu kredit ini menjadi kebutuhan } \\
\text { yang mendesak bagi masyarakat untuk } \\
\text { keamanan, keefektifan dan kenyamanan } \\
\text { dalam bertransaksi atau dalam } \\
\text { bermuamalah. }\end{array}$ \\
\hline
\end{tabular}

\begin{tabular}{lll}
\hline 45/DSN- & Line Facility & Fatwa ini melegitimasi LKS untuk \\
MUI/II/20 & (At- & memberikan pelayanan berupa fasilitas \\
05 & Thashilat & plafon pembiayaan yang diberikan kepada \\
& As- & nasabah tertentu dalam jangka waktu \\
& tertentu yang dijalankan berdasarkan \\
& prinsip syariah. Fasilitas ini dilakukan \\
& berdasarkan wa'd dan dapat digunakan \\
& untuk pembiayaan tertentu. Fatwa ini tidak \\
& menegaskan batasan kebutuhan sebagai \\
& dasar nasabah untuk mengajukan \\
& pembiayaan.
\end{tabular}

\begin{tabular}{lll}
\hline 10. & 54/DSN- & Syariah \\
MUI/X/20 & Card \\
06 &
\end{tabular}

Fatwa ini melegitimasi penggunaan Kartu Kredit Syariah. Kartu kredit yaitu sebagai alat pembayaran dengan menggunakan kartu yang dapat digunakan untuk melakukan pembayaran atas kewajiban yang timbul dari suatu kegiatan ekonomi, termasuk transaksi pembelanjaan dan atau untuk melakukan penarikan tunai, di mana kewajiban pembayaran pemegang kartu dipenuhi terlebih dahulu oleh acquirer atau penerbit, dan pemegang kartu berkewajiban melakukan pelunasan kewajiban pembayaran tersebut pada waktu yang disepakati secara angsuran. Akad-akad yeng mungkin terjadi dalam penggunaan kartu kredit ini adalah, kafālah, qard, dan akad ijārah. Fasilitas 


\begin{tabular}{|c|c|c|c|}
\hline & & & $\begin{array}{l}\text { kartu kredit ini menjadi kebutuhan yang } \\
\text { mendesak bagi masyarakat untuk } \\
\text { keamanan, efektifitas, efisiensi dan } \\
\text { kenyamanan dalam bertransaksi atau } \\
\text { dalam bermuamalah. }\end{array}$ \\
\hline 11. & $\begin{array}{l}\text { 55/DSN- } \\
\mathrm{MUI} / \mathrm{V} / 20 \\
07\end{array}$ & $\begin{array}{l}\text { Pembiayaan } \\
\text { Rekening } \\
\text { Koran } \\
\text { Syariah } \\
\text { Musyarakah }\end{array}$ & $\begin{array}{l}\text { Fatwa ini melegitimasi LKS untuk } \\
\text { mengambil upah (ujrah) dari jasa atau } \\
\text { fasilitas reking koran syariah musyārakah } \\
\text { dan melegitimasi diperbolehkannya } \\
\text { Pembiayaan Rekning Koran Syariah } \\
\text { (PRKS) yang dapat pula dilakukan degan } \\
\text { wa'd dalam pemberian fasilitas } \\
\text { perkongsian (musyārakah). Fatwa ini tidak } \\
\text { memberikan batasan dan kriteria } \\
\text { kebutuhan pinjaman melalui akad } \\
\text { (musyārakah) yang diajukan nasabah, } \\
\text { apakah kebutuhan primer, skunder atau } \\
\text { hanya kebutuhan tersier. }\end{array}$ \\
\hline 12. & $\begin{array}{l}\text { 60/DSN- } \\
\text { MUI/V/20 } \\
07\end{array}$ & $\begin{array}{l}\text { Penyelesaian } \\
\text { Piutang } \\
\text { Dalam } \\
\text { Ekspor }\end{array}$ & $\begin{array}{l}\text { Fatwa ini melegitimasi pihak LKS untuk } \\
\text { mengambil fee atas jasa dan fasilitasnya } \\
\text { menrus dokumen dan jasa penagihan utang } \\
\text { kepada pihak importir yang berhutang } \\
\text { kepada eksportir. Fee tersebut diambil diri } \\
\text { pihak eksportir yang mempunyai piutang. } \\
\text { Akad dalam fasilitas dan jasa semacam ini } \\
\text { adalah akan adalah akad wakälah bi ujrah } \\
\text { yang dapat disertai dengan akad qard. } \\
\text { Fasilitas penyelesaian piutang ekspor } \\
\text { dengan konsekuensinya yang berupa fee } \\
\text { dipandang sebagai kebutuhan mendesak } \\
\text { masyarakat yang harus dipenuhi oleh LKS, } \\
\text { agar akad yang dijalankan sesuai dengan } \\
\text { ketentuan syara'. }\end{array}$ \\
\hline 13. & $\begin{array}{l}61 / \mathrm{DSN}- \\
\mathrm{MUI} / \mathrm{V} / 20 \\
07\end{array}$ & $\begin{array}{l}\text { Penyelesaian } \\
\text { Utang } \\
\text { Dalam } \\
\text { Impor }\end{array}$ & $\begin{array}{l}\text { Fatwa ini hampir sama dengan fatwa DSN- } \\
\text { MUI nomor 60/DSN-MUI/V/2007, hanya } \\
\text { saja fatwa ini berkaitan dengan utang } \\
\text { dalam impor. Perbedaan lain adalah, akad } \\
\text { yang digunakan dalam jasa dan fasilitas } \\
\text { yang diberikan LKS kepada nasabah } \\
\text { adalah akad hawälah bil ujrah. Fasilitas } \\
\text { penyelesaian hutang dalam impor dengan } \\
\text { konsekuensinya yang berupa fee } \\
\text { dipandang sebagai kebutuhan mendesak } \\
\text { masyarakat yang harus dipenuhi oleh LKS, } \\
\text { agar akad yang dijalankan sesuai dengan } \\
\text { ketentuan syara, }\end{array}$ \\
\hline
\end{tabular}




\begin{tabular}{|c|c|c|c|}
\hline 14. & $\begin{array}{l}\text { 53/DSN- } \\
\mathrm{MUI} / \mathrm{XII} / 2 \\
007\end{array}$ & $\begin{array}{l}\text { Sertifikat } \\
\text { Bank } \\
\text { Indonesia } \\
\text { Syariah } \\
\text { (SBIS) }\end{array}$ & $\begin{array}{l}\text { Fatwa ini melegitimasi pengeluaran } \\
\text { Sertifikat Bank Indonesia Syariah (SBIS) } \\
\text { sebagai instrumen pengendalian moneter. } \\
\text { Sertifikat ini merupakan surat berharga } \\
\text { dalam mata uang rupiah dalam jangka } \\
\text { waktu yang pendek dan berdasarkan } \\
\text { prinsip syariah menggunakan akad } \\
\text { mud̄ärabah, musyārakah, ju'àlah, } \\
\text { wadi'ah. Qard dan wakālah. }\end{array}$ \\
\hline 15. & $\begin{array}{l}\text { 64/DSN- } \\
\mathrm{MUI} / \mathrm{XII} / 2 \\
007\end{array}$ & $\begin{array}{l}\text { Sertifikat } \\
\text { Bank } \\
\text { Indonesia } \\
\text { Syariah } \\
\text { Ju'alah } \\
\text { (SBIS } \\
\text { Ju'alah) }\end{array}$ & $\begin{array}{l}\text { Fatwa ini melegitimasi pengeluaran } \\
\text { Sertifikat Bank Indonesia Syariah Juālah } \\
\text { (SBIS) Ju'älah sebagai instrumen } \\
\text { optimalisasi pengendalian moneter. } \\
\text { Sertifikat ini merupakan surat berharga } \\
\text { dalam mata uang rupiah dalam jangka } \\
\text { waktu yang pendek dan berdasarkan } \\
\text { prinsip syariah menggunakan akad ju'ālah. } \\
\text { BI akan memberikan reward bagi Bank } \\
\text { Syariah yang berpartisipasi secara optimal } \\
\text { dalam mengendalikan moneter. }\end{array}$ \\
\hline 16. & $\begin{array}{l}\text { 79/DSN- } \\
\text { MUI/III/20 } \\
11\end{array}$ & $\begin{array}{l}\text { Qardh } \\
\text { Dengan } \\
\text { Menggunaka } \\
\text { n Dana } \\
\text { Nasabah }\end{array}$ & 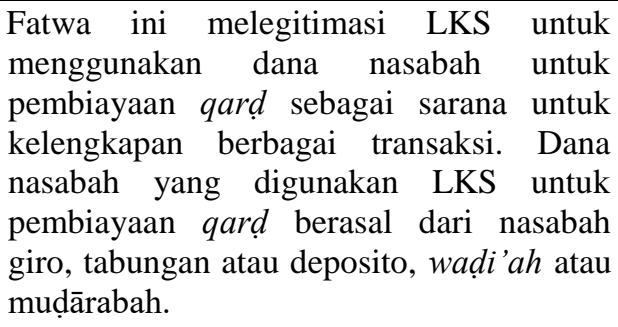 \\
\hline 17. & $\begin{array}{l}87 / \mathrm{DSN}- \\
\mathrm{MUI} / \mathrm{XII} / 2 \\
012\end{array}$ & $\begin{array}{l}\text { Metode } \\
\text { Pengaturan } \\
\text { Pendapatan } \\
\text { Dan } \\
\text { Cadangan } \\
\text { Penyesuaian } \\
\text { Keuntungan } \\
\text { (Profit } \\
\text { Equalization } \\
\text { Reserve) } \\
\text { dalam Bagi } \\
\text { Hasil Dana } \\
\text { Pihak Ketiga } \\
\end{array}$ & $\begin{array}{l}\text { Fatwa ini melegitimasi penggunaan } \\
\text { metode pengaturan pendapatan tanpa } \\
\text { bentuk cadangan penyesuaian keuntungan } \\
\text { dan metode pengaturan pendapatan dengan } \\
\text { bentuk cadangan penyesuaian keuntungan. } \\
\text { Metode pengaturan pendapatan merupakan } \\
\text { metode pengaturan distribusi keuntungan } \\
\text { dari waktu ke waktu atas bagi hasil antara } \\
\text { LKS dengan nasabah. }\end{array}$ \\
\hline 18. & $\begin{array}{l}\text { 39/DSN- } \\
\text { MUI/X/20 } \\
02\end{array}$ & $\begin{array}{l}\text { Asuransi } \\
\text { Haji }\end{array}$ & $\begin{array}{l}\text { Fatwa ini melegitimasi asuransi haji } \\
\text { dengan prinsip syariah yang bersifat } \\
t^{\prime} \bar{a} w u n \bar{l} \text { dengan akad hibah dengan tujuan } \\
\text { untuk saling menolong sesama jamaah } \\
\text { haji. }\end{array}$ \\
\hline
\end{tabular}




\begin{tabular}{|c|c|c|c|}
\hline 19. & $\begin{array}{l}\text { 32/DSN- } \\
\text { MUI/IX/20 } \\
02\end{array}$ & $\begin{array}{l}\text { Obligasi } \\
\text { Syariah } \\
(S, u k \bar{u} k)\end{array}$ & 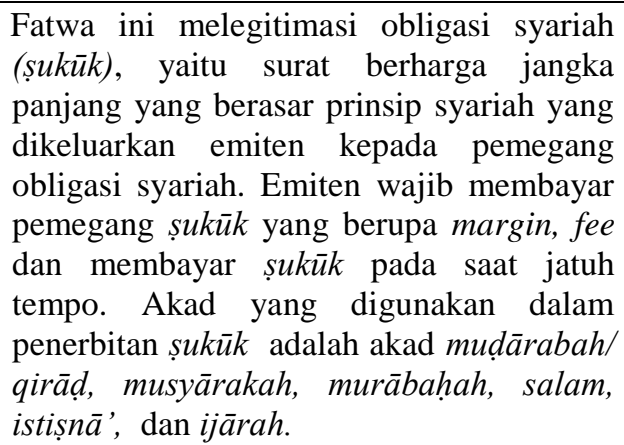 \\
\hline
\end{tabular}

\begin{tabular}{|c|c|c|c|}
\hline 20. & $\begin{array}{l}\text { 33/DSN- } \\
\mathrm{MUI} / \mathrm{IX} / 20 \\
02\end{array}$ & $\begin{array}{l}\text { Obligasi } \\
\text { Syariah } \\
\text { (Șukūk) } \\
\text { Muḍārabah }\end{array}$ & 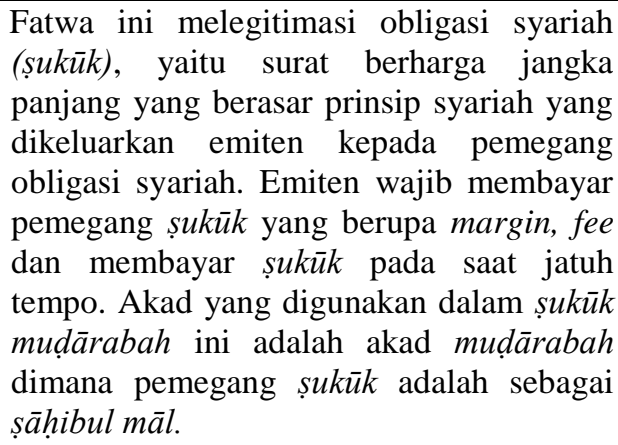 \\
\hline
\end{tabular}

21. 59/DSN- Obligasi $\quad$ Fatwa ini melegitimasi konversi obligasi MUI/V/20 Syariah syariah (sukūk), yaitu surat berharga $07 \quad(S u k \bar{u} k)$ jangka panjang yang berasar prinsip

Mudharabah syariah yang dikeluarkan emiten kepada Konversi pemegang obligasi syariah. Emiten wajib membayar pemegang sukük yang berupa margin, fee dan membayar șukūk pada saat jatuh tempo. Akad yang digunakan dalam șukūk mudāarabah ini adalah akad muḍārabah dimana pemegang șukūk adalah sebagai șāhibul māl. Pemegang șukūk diperbolehkan menggunakan haknya untuk mengonversi șukūk menjadi saham emiten dengan menggunakan akad musyārakah.

\begin{tabular}{lll}
\hline 22. & 68/DSN- & Rahn Tasjilī \\
& MUI/III/20 & \\
& 08
\end{tabular}

Fatwa ini melegitimasi penyerahan barang jaminan atas utang oleh nasabah, dalam hal ini bukan barang atau obyeknya yang diserahkan, namun hanya surat bukti sah kepemilikan barang tersebut, sementara barang masih dalam penguasaan dan pemanfaatan pemberi jaminan.

\begin{tabular}{llll}
\hline 23. & 67/DSN- & Anjak & Fatwa ini melegitimasi pengalihan \\
& MUI/III/200 & Piutang & penyelesaian piutang atau tagihan jangka \\
\hline
\end{tabular}




\begin{tabular}{|c|c|c|c|}
\hline & & Syariah & $\begin{array}{l}\text { pendek dari pihak yang berpiutang kepada } \\
\text { pihak lain yang kemudian ia menagih } \\
\text { piutangtersebut kepada pihak yang } \\
\text { berhutang atau pihak yang ditunjuk oleh } \\
\text { pihak yang berhutang sesuai dengan } \\
\text { prinsip syariah. Akad yang digunakan } \\
\text { dalam transaksi ini adalah akad wakālah } \\
\text { bil ujrah. }\end{array}$ \\
\hline 24. & $\begin{array}{l}\text { 74/DSN- } \\
\text { MUI/I/200 } \\
9\end{array}$ & $\begin{array}{l}\text { Penjaminan } \\
\text { Syariah }\end{array}$ & $\begin{array}{l}\text { Fatwa ini melegitimasi jaminan antara para } \\
\text { pihak yang melakukan suatu transaksi } \\
\text { berdasarkan prinsip syariah. Akad yang } \\
\text { digunakan adalah akad kafälah bil ujrah. } \\
\text { Fatwa ini merinci kreteria jaminan yang } \\
\text { diperbolehkan. }\end{array}$ \\
\hline
\end{tabular}

Tabel di atas menegaskan tingginya intensitas penggunaan kaidah al-hājah qad tunazzalu manzilah al-darurah dalam fatwa DSN-MUI yang terkait dengan berbagai jenis mu'amalah. Pada umumnya mu'amalah yang dilegitimasi dengan fatwa yang menggunakan kaidah tersebut mu'amalah menggunakan akad al-bai', ijārah, ju'ālah, muḍārabah, musyārakah, wadì'ah. Qarḍ,wakālah, kafälah, dan bentuk akad lain yang sesuai dengan prinsip syariah.

\section{Analisis Penggunaan Kaidah Al-Häjah Qad Tunazzalu Manzilah Al-Darurah Dalam Fatwa DSN-MUI}

\section{Makna Kaidah}

Menurut al-Baqillānī, al-hājah secara terminologi pada dasarnya sama dengan al-darūrah. ${ }^{32}$ Hājah merupakan keadaan yang membutuhkan kemudahan agar tujuan dapat tercapai dengan mudah. ${ }^{33}$ Definisi hạjah yang paling komprehensif adalah definisi yang dikemukakan oleh al-Syāțibī, yaitu:

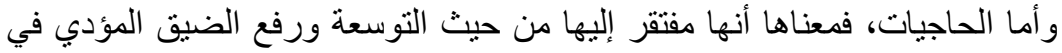

$$
\begin{aligned}
& \text { الغالب إلى الحرج و المشقة اللاحقة بفوت المطلوب، فإذا لم تر اع دخل على علتى المكلفين- }
\end{aligned}
$$

${ }^{32}$ Muḥammad bin Țayyib bin Muhammad bin Ja'far bin al-Qāsim alBaqillānī, al-Tamhīd (Beirut - Lebanon: al-Maktabah al-Syarqiyah, 1957), 27.

${ }^{33}$ Syekh Ahmad bin Syekh Muhammad Al-Zarqa, Syarh al-Qawa'id alFiqhiyyah (Damaskus: Dar al-Qolam, 1989), 209; Muhammad Mușṭafā al-Zuhailī, al-Qawāid al-Fiqhiyyah wa Tațbīqatuhā fì al-Mdzāhib al-Arbaáh, vol. 1 (Damaskus: Dār al-Fikr, 2009), I/288. 


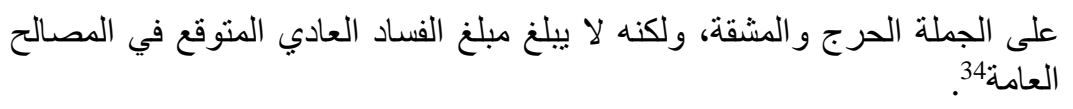

Al-ḥājah menurut al-Syāțibī ada dua macam, al-ḥājah āmmah dan al-hājah al-khāṣṣah. Al-ḥajjah āmmah dalam Bahasa al-Syāțibī disebut juga al-hājah al-kuliyyah yang hukumnya selalu berlaku, meskipun meskipun keadaan mendesak yang menjadi landasan telah tiada, seperti diperbolehkannya akad ijārah. Sementara al-hājah alkhạșsah disebut juga dengan rukhṣah, yaitu dispensasi atau keringanan yang hanya berlaku untuk perorangan dalam kondisi dan waktu tertentu saja. ${ }^{35}$

Kaidah ini menunjukkan bahwa pengecualian untuk melakukan suatu yang terlarang tidak hanya terbatas pada suatu yang darurat semata, akan tetapi juga berlaku pada suatu yang menjadi kebutuhan mendesak. ${ }^{36}$ Baik kebutuhan tersebut bersifat khusus menyangkut sekelompok masyarakat, amupun kebutuhan umum yang berlaku bagi selutuh masyarakat. Kaidah ini tidak hanya melegitimasi melakukan suatu yang di larang, tetapi juga berkonsekuensi pada diperbolehkannya meninggalkan yang wajib saat ada hajat yang mendesak. ${ }^{37}$

Para ahli hukum, termasuk anggota DSN-MUI harus jeli dalam menggunakan kaidah ini, terutama harus memperhatikan perbedaan antara darurahī dengan hăjah. Kedua lafazh ini berbeda, dan perbedaan ini berimplikasi pada konsekuensi hukumnya. Setidaknya ada beberapa perbedaan antara dua lafazh ini, yaitu:

a. Darürah lebih mendesak dari häjah. ${ }^{38}$ Darürah memberikan ruang diperbolehkannya suatu yang dilarang dalam rangka penyelesaian masalah yang tidak mungkin dibiarkan begitu saja. Sementara

${ }^{34}$ Abū Ishạa bin Ibrāhīm al-Syātịīi, al-Muwāfaqāt (Beirut - Lebanon: Dar al-Kutub al-'Ilmiyah, 2003), I/220.

${ }^{35}$ Imām Jalāluddīn Abdurraḥmān As-Suyūṭ̄, al-Asybah Wa al-Nadzā 'ir fì Qawā'idi wa Furū' Fiqh al-Syāfi 'iyah (Riya: Maktabah Nazzār Al-Baz, 1997), 61 Baca juga; Zainuddīn bin Ibrāhīm bin Muḥammad Ibnu Nujaim, Al-Asybah wa alNaz̄āir 'ala Madzhab Abī Hanīfah al-Nu'mān (Beirut - Lebanon: Dār al-kutub al'Ilmiyyah Beirut, 1999), 65.

36 'Izzāt Ubaid al-Di'ās, al-Qawā'id al-Fiqhiyyah m'a Syarh al-Mūjaz (Beirut - Lebanon: Dar al-Tarmidzī, 1989), 45.

${ }^{37}$ Kementerian Wakaf Kuwait, al-Mausū'ah al-Fiqhiyyah al-Kuwaitiyyah (Kuwait: Dār al-Salāsil, 1404), XVI/256.

38 al-Di'ās, al-Qawā'id al-Fiqhiyyah m'a Syarh al-Mūjaz, 45. 
hājah dipenuhi atau dilakukan dalam rangka mempermuadah suatu urusan, dan tidak mendesak.

b. Darūrah_bisa menjadi alasan diperbolehkan suatu yang dilarang, baik menyangkut orang banyak atau hanya perseorangan. Sementara hājah harus berkaitan dengan orang banyak. ${ }^{39}$ Arti kata 'khāsșah dalam kaidah al-hajjah qad tunazzalu manzilah aldarūrah ämmah kanat aw khāsșah bukan lah perseorangan, akan tetapi kelompok masyarakat seperti suku atau bangsa tertentu. ${ }^{40}$

c. Darurah bisa menjadi alasan diperbolehkan suatu yang dilarang, sementara hājah tidak, kecuali hājah āmmah;

d. hukum yang ditetapkan karena alasan darūrah hanya berlaku saat adanya d̦rūrah tersebut, ia terbatas waktu. Sementara hukum yang ditetapkan berdasarkan hajjah tidak terbatas waktu. ${ }^{41}$

e. Setiap darūrah adalah hăjah, namun tidak setiap ḥajjah adalah darūrah. ${ }^{42}$

Meskipun ada perbedaan antara darūrah dan hājjah, namun keduanya juga memiliki persamaan. Darūrah dan hājah sama sama dapat menjadi alasan perubahan hukum, baik diperbolehkannya yang dilarang, atau dalam bentuk meninggalkan yang diperintah. Selain itu, keduanya sama sama hanya berlaku selama untuk memenuhi dalam kondisi darurat atau karena ada keperluan semata, tidak lebih dari itu. ${ }^{43}$

2. Ketentuan Pengguaan Kaidah al-hājah qad tunazzalu manzilah al-darurah

Kaidah al-hājah qad tunazzalu manzilah al-darurah dapat diimplementasikan dalam berbagai mu'amalah yang tidak ada nașs nya dan tidak bisa diqiyaskan. Mu'amalah-mu'amalah kontemporer yang menjadi kebutuhan mendesak bagi masyarakat, baik dalam bidang perdagangan maupun jasa, dan sekiranya bila tidak

${ }^{39}$ Ṣāliḥ bin Ghānim al-Sadlān, al-Qawā'id al-Fiqhiyyah al-Kubrā wa mā Tafarra'a 'Anhà (Riyaḍ: Dār al-Balansiyah, 2000), 289.

${ }^{40}$ al-Di'ās, al-Qawā'id al-Fiqhiyyah m'a Syarh al-Mūjaz, 45.

${ }^{41}$ al-Zuhailī, al-Qawāid al-Fiqhiyyah wa Tațbīqatuhā fì al-Mdzāhib alArbaáh, 1:I/290.

${ }^{42}$ al-Sa'dī al-Sa'dī, Qāídah al-hājah Tunazzilu Manzilah al-Darūrah wa Tațbīqatuhā fì al-Fiqh al-Aqalliyāt al-Muslimah (Riyaụ: Tp., Tt), 49.

${ }^{43}$ al-Sadlān, al-Qawā'id al-Fiqhiyyah al-Kubrā wa mā Tafarra'a 'Anhā, $288-89$. 
diperbolehkan aka menimbulkan mempersulit masyarakat untuk memenuhi kebutuhan mereka, maka diperbolehkan dengan ketentuan samapai kesulitan yang dihadapi bisa terselesaikan. ${ }^{44}$ Hanya saja, diperbolehkannya suatu yang dilarang karena hajat terbatas pada pemenuhian kebutuhan saja, tidak boleh lebih dari itu, sebagaimana darūrah hanya diperbolehkan sekiranya sampai batas hilangnya darūrah atau keadaan mendesak tersebut. ${ }^{45}$

Kebutuhan menempati posisi darurat itu dalam kaitannya dengan penetapan hukum. Hanya saja bedanya, keadaan darurat terbatas oleh waktu, sementara, kebutuhan itu tidak dibatasi oleh waktu atau selalu ada. Hukum yang ditetapkan berdasakan hājah berlaku umum, tidak terbatas sebagaimana hukum yang ditetapkan berdasarkan adat atau kebiasaan. ${ }^{46}$

Suatu yang diperbolehkan berdasarkan pertimbangan hājah atau kebutuhan, maka ada nașs yang melegitimasinya atau tidak, atau tidak ada nașs yang melarangnya, maka hal itu diperbolehkan. Namun demikian, apabila penemuhan suatu kebutuhan tidak ada nașs yang melegitimasinya dan tidak menjadi kebiasaan masyarakat, tidak ada celah untuk diqiyas, serta tidak mendatangkan maslahat yang nyata, maka pemenuhan kebutuhan tersebut tidak boleh. ${ }^{47}$

Berdasarkan kaidah ini, menurut padandangan ulama bahwa kebutuhan bisa menjadi landasan penetapan hukum sebagaimana darurat pada kondisi dan situasi tertentu, yaitu kebutuhan yang mendesak. Suatu yang menurut sekelompok orang bisa jadi merupakan darurat menurut orang tertentu. ${ }^{48}$

Syarat-syarat yang harus dipenuhi dalam penggunaan kaidah al-hājah qad tunazzalu manzilah al-ḍaūrah ämmah kanat aw khāsșah:

44 al-Zuhailī, al-Qawāid al-Fiqhiyyah wa Tațbīqatuhā fì al-Mdzāhib alArbaáh, 1:I/294. 295.

${ }^{45}$ al-Sadlān, al-Qawā'id al-Fiqhiyyah al-Kubrā wa mā Tafarra'a 'Anhā,

${ }^{46}$ Syekh Ahmad bin Syekh Muhammad Al-Zarqa, Syarh al-Qawa'id alFiqhiyyah (Damaskus: Dar al-Qolam, 1989), 209 Bacajuga; Muḥammad Muștafā al-Zuhailīi, al-Qawāíd al-Fiqhiyyah wa Tațbīqatuhā fì al-Mdzāhib al-Arbaáh, vol. 1 (Damaskus: Dār al-Fikr, t.t.), I/298.

${ }^{47}$ Al-Zarqa, Syarh al-Qawa'id al-Fiqhiyyah, 210.

${ }^{48}$ Baca al-Sa'dī, Qāidah al-hājah Tunazzilu Manzilah al-Darūrah wa Taṭbìqatuhā fì al-Fiqh al-Aqalliyāt al-Muslimah. 
a. hājah harus benar-benar nyata dan mendesak, bukan suatu yang berdasarkan asumsi. Apabila hājah tersebut tidak terpenuhi, maka akan menimbulkan kesulitan atau bahkan bila dibiarkandapat menimbulkam kerusakan.

b. hăjah jelas dan spesifik dimana tidak bisa digantikan dengan suatu yang lain.

c. häjah merupakan suatu yang umum dan wajar, bukan suatu yang aneh dan tidak lazim;

d. al-Sa' dī menegaskan, "al-hâjah filqad̄àyā allatī hurrimat wasāil, aw hurrimat saddan li al-zdarì'ah, wa laisat manhiyyatan aw muharraman lidzatihi." Hājah bukan merupakan suatu yang dilarang karena zhat-nya, akan tetapi dilarang karena statusnya sebagai suatu yang menjadi perantara bagi suatu yang lain, atau dilarang karena dapat menimbulkan kerusakan.

e. Hendaknya adanya ketetapan hukum dispensasi karena adanya hajat ditetapkan berdasarkan nașs, atau ijma' amalī, atau qiyas, atau secara nyata benar-benar mendatangkan kemaslahatan. ${ }^{49}$

Menurut Sadalan, hājah dalam kaidah al-hājah Tunazzilu Manzilah al-Darürah harus memenuhi syarat sebagai berikut:

a. hājjah tidak sampai menganulir yang asal, yaitu darūrah; sebagai cabang, hajjah tidak boleh membatalkan yang pokok.

b. häjah merupakan suatu yang mendesak saat ini, bukanuntuk masa yang akan datang;

c. pemenuhan hājah tidak bertentangan dengan syara' ${ }^{50}$ Berkaitan degan ini al-Syāțibī pernah menyatakan:

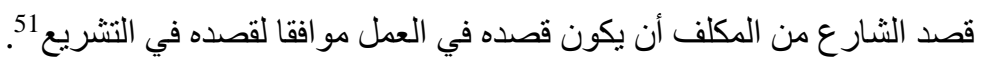

Sementara menurut al-Warad, persayaratan hājah yang menempati posisi darurat adalah sebagai berikut: pertama, hajat harus hajat yang mendesak yang saat dibutuhkan harus terpenuhi, bukan kebutuhan masa yang akan datang atau kebutuhanmasa depan; kedua,

${ }^{49}$ Walīd Șalāḥuddīn al-Zair, "Dawābit al-Ḥājah al-Latī Tanzilu Manzilah al-Ḍarurah wa Tatbīqatuha 'ala al-Ijthād al-Mu'așirah," Majallah Jāmi'ah Dasakus li al- 'Ulūm al-Iqtiṣādiyyah wa al-Qānūniyyah 26, no. 2 (2010): 682-83 Baca juga; al-Sa'dī, Qāídah al-ḥajjah Tunazzilu Manzilah al-Ḍarūrah wa Tațbīqatuhā fì alFiqh al-Aqalliyāt al-Muslimah, 46-48. $290-91$.

${ }^{50}$ al-Sadlān, al-Qawā'id al-Fiqhiyyah al-Kubrā wa mā Tafarra'a 'Anhā,

${ }^{51}$ al-Syātịīī, al-Muwāfaqāt, III/23. 
pemenuhan hajat dalam konteks kaidah ini tidak menimbulkan terjadinya perbuatan atau suatu yang bertentangan dengan hukum syar'i. Artinya, bila hajat yang dimaksud dalam kaidah tersebut terpenuhi, tidak menimbulkan terjadinya suatu yang di larang. Ketiga, hajat yag menempati posisi darurat adalah hajat yang sebatas hanya untuk memenuhi kebutuhan saat itu juga, tidak ada kelebihan atau untuk memenuhi kebutuhan yang akan datang. ${ }^{52}$

Kata kunci yang menjadi acuan penetapan hukum dalam kaidah al-ḥajjah qad tunazzalu manzilah al-ḍaūrah ämmah kanat aw khāsșah adalah kata häjah. Kata ini bila diterjemahkan secara sederhana berarti kebutuhan, namun dalam kaidah ini berarti kebutuhan mendesak yang harus dipeuhi. Apabila tidak dipenuhi, maka akan menyulitkan masyarakat, terutma dalam pemenuhan kebutuhan yang terkait.

Kata hăjah dalam kaidah berarti kebutuhan sebagai sarana (wașilah), yaitu perantara untuk memenuhi suatu yang lain. Artinya, sesuatu yang harus dipenuhi (yang memperbolehkan suatu yang dilarang) tersebut bukan zatī atau zatnya, akan tetapi hanya perantara untuk memenuhi suatu yang lain yang juga dibutuhkan.

Berdasarkan paparan di atas, maka penggunaan kaidah alhājah qad tunazzalu manzilah al-ḍarūrah āmmah kanat aw khāṣsah dalam fatwa-fatwa DSN-MUI sudah tepat, karena pada umumnya, fatwa-fatwa tersebut untuk melegitimasi produk layanan atau fasilitas Lembaga Keuangan Syariah (LKS) yang dibutuhkan oleh masyarakat. Dari 23 fatwa yang menggunakan kaidah tersebut, semuanya melegitimasi fasilitas dan produk yang dibutuhkan oleh masyarakat, terutama kebutuhan yang diperlukan masyarakat seiring dengan perkembangan teknologi dan aktifitas perekonomian dan bisnis.

Namun demikian, mayoritas fatwa dari 23 fatwa tersebut tidak menegaskan jenis kebutuhan yang diperbolehkan menggunakan fasilitas atau produk yang dilegitimasi dengan fatwa yang mengunakan kaidah di atas. Hanya beberapa fatwa saja yang memberikan penegasan secara detail ketentuan dan syarat diperbolehkannya menggunakan fasilitas layanan dan produk tertentu dari Lembaga Keuangan Syariah.

52 al-Warad, Atsaru Qāidah al-hājah Tunazzilu Manzilah al-Ḍarūrah fì Isqāṭi Úqūbah al-Sirqah fì Fiqh al-Jināi al-Mu-āṣir, 1183. 


\section{E. Keseimpulan}

Kaidah al-hājah qad tunazzalu manzilah al-darūrah āmmah kanat aw khāsșah memberi ruang yang longgar bagi para ahli hukum untuk menetapkan hukum suatu perkara yang menjadi kebutuhan masyarakat. Kata kunci al-ḩajjah dalam kaidah ini mempunyai implikasi hukum yang jelas, yaitu suatu yang diperlukan oleh kelompok masyarakat yang harus terpenuhi untuk memudahkan pemenuhan kebutuhan yang terkait. Artinya tidak semua kebutuhan masyarakat dapat dilegitimasi dengan kaidah ini.

Fatwa Dewan Syariah-Majelis Ulama Indonesia tetang keuangan syariah dari tahun 2000-tahun 2012 banyak yang menggunakan kaidah di atas sebagai landasan. Tingginya intensitas penggunaan kaidah al-hājah qad tunazzalu manzilah al-darūrah ammah kanat aw khāsșah dalam fatwa yang terkait dengan keuangan syariah menunjukkan bahwa kaidah ini cukup diperhitungkan dalam menjawab problem masyarakat terkait dengan keuangan syariah. Penggunaan kaidah ini oleh DSN-MUI sebagai dasar penetapan hukum dalam fatwa terkait produk dan layanan Lembaga Keuangan Syariah (LKS) yang dibutuhkan oleh masyarakat sudah tepat dan dapat menjawab problem hukum ekonomi di Indonesia. Hanya saja, DSN-MUI nampaknya perlu penegasan dalam fatwa mengenai kriteria kebutuhan terhadap produk dan layanan LKS tersebut. [.]

\section{Referensi}

Al-Qorofi, Imam Abul Abbas Ahmad bin Idris Ash-Shonhaji. AlFuruq / Anwarul Buruq Fi Anwa'il Furuq. Beirut - Lebanon: Darul Kutub Al-Ilmiyah, 1998.

Al-Zarqa, Syekh Ahmad bin Syekh Muhammad. Syarh al-Qawa'id al-Fiqhiyyah. Damaskus: Dar al-Qolam, 1989.

Ansori, Isa. "Kedudukan Fatwa di Beberapa Negara Muslim (Malaysia, Brunei Darussalam dan Mesir)." Analisis: Jurnal Studi Keislaman 17, no. 1 (28 November 2017): 137. doi:10.24042/ajsk.v17i1.1790.

ās, 'Izzāt Ubaid al-Di'. al-Qawā'id al-Fiqhiyyah m'a Syarh al-Mūjaz. Beirut - Lebanon: Dar al-Tarmidz̄i, 1989. 
As-Suyūṭị, Imām Jalāludd̄̄n Abdurraḥmān. al-Asybah Wa alNadzā'ir fì Qawā'idi wa Furū' Fiqh al-Syāfi'iyah. Riya: Maktabah Nazzār Al-Baz, 1997.

Baqillān̄̄, Muḥammad bin Ṭayyib bin Muḥammad bin Ja'far bin alQāsim al-. al-Tamhīd. Beirut - Lebanon: al-Maktabah alSyarqiyah, 1957.

Burnū, Muḥammad Șidqī bin Aḥmad al-. Majmū'ah al-Qawā'id alFiqhiyyah: Jam'wa Tartīb wa Bayān. Riyaḍ: Maktabah alTaubah, 1997.

Denzin, Norman K., dan Yvonna S. Lincoln. Hand Book of Qualitative Research. Yogyakarta: Pustaka Pelajar, 2009.

dī, al-Sa'dī al-Sa'. Qāidah al-hājah Tunazzilu Manzilah al-Darūrah wa Tațbìqatuhā fì al-Fiqh al-Aqalliyāt al-Muslimah. Riyaḍ: Tp., Tt.

Elgariani, Fawzy Shaban. “Al-Qawa'id Al-Fiqhiyyah (Islamic Legal Maxims): Concept, Functions, History, Classifications and Application to Contemporary Medical Issues," 10 Februari 2012. https://ore.exeter.ac.uk/repository/handle/10036/4001.

Hakim, Atang Abd, dan Sofyan al-Hakim. "“Kerangka Penyelesaian Sengketa Bisnis Syariah,." AT - TARADHI Jurnal Studi Ekonomi 6, no. 1 (2015).

Hariyanto, Erie. "Penyelesaian Sengketa Ekonomi Syariah di Indonesia." Iqtishadia al-Ihkâm 1, no. 1 (Jun i 201 4).

Hasyim, Syafiq. "The Council of Indonesian Ulama (Majelis Ulama Indonesia, MUI) and Religious Freedom." Irasec's Discussion Papers, 12 Desember 2011.

Hidayah, Nur. "Fatwa-fatwa Dewan Syariah Nasional Atas Aspek Hukum Islam Perbankan Syariah di Indonesia." $A L$ 'ADALAH X, no. 1 (Januari 2011).

Hilal, Syamsul. "Qawâ'Id Fiqhiyyah Furû'Iyyah Sebagai Sumber Hukum Islam." AL-'ADALAH 11, no. 2 (28 Februari 2013): 141-54.

Ibnu Nujaim, Zainuddīn bin Ibrāhīm bin Muḥammad. Al-Asybah wa al-Nazāir 'ala Madzhab Abī Hanīfah al-Nu'mān. Beirut Lebanon: Dār al-kutub al-'Ilmiyyah Beirut, 1999. 
Jum'ah, Ímād Alī. al-Qawāíd al-Fiqhiyyah al-Muyassarah. Kairo: Tp., 2006.

Kamali, Mohammad Hashim. "Legal Maxims and Other Genres of Literature in Islamic Jurisprudence." Arab Law Quarterly 20, no. 1 (2006): 77-101.

. "Qawa "id Al-Fiqh: The legal maxims of Islamic law." The Association of Muslim Lawyers, 2008.

Kementerian Wakaf Kuwait. al-Mausū'ah al-Fiqhiyyah alKuwaitiyyah. Kuwait: Dār al-Salāsil, 1404.

Krippendorff, Klaus. Content Analysis; an Indtroduction to Its Methodology. London: Sage Publication, 2004.

Maskufa, Maskufa. "Penyelesaian Sengketa Perjanjian Syariah pada Lembaga Keuangan Syariah." Al-Iqtishad Journal of Islamic Economics 5, no. 1 (Januari 2013). https://www.neliti.com/id/publications/195018/penyelesaiansengketa-perjanjian-syariah-pada-lembaga-keuangan-syariah.

Masud, Muhammad Khalid, Brinkley Messick, dan David. S Powers, ed. Islamic Legal Interpretation: Muftis and Their Fatwas. London: Hardvard University Press, 1996.

Mohammaed, Khaleel. "The Islamic Law Maxims." slamic Studies 44, no. 2 (2005): 191-207.

Mubarok, Jaih, dan Hasanudin. "Dinamika fatwa produk keuangan syariah." Ijtihad, Jurnal Wacana Hukum Islam dan Kemanusiaan 13, no. 1 (1 Juni 2013).

Musa, Khadiga. "Legal Maxims as a Genre of Islamic Law Origins, Development and Significance of Al-Qawā'id al-Fiqhiyya." Islamic Law and Society 21 (2014): 325-65.

Nadwi, 'Ali Ahmad al-. al-Qawa'id al-Fiqhiyyah. Damaskus: Dar alQolam, 1998.

Novia, Aidil. "Kontribusi Fiqh Legal Maxim dalam Fatwa-Fatwa Ekonomi Syariah Dewan Syariah Nasional Majelis Ulama Indonesia (DSN-MUI)." TSAQAFAH 12, no. 1 (14 Mei 2016): 79. doi:10.21111/tsaqafah.v12i1.369.

Pakeeza, Shahzadi. "Role of Al- Qaw 7 i'd Al-Fiqhiyya (Islamic Legal Maxims) in $\mathrm{Ijtih}_{\rceil} \mathrm{d} "$ 5, no. 2 (2014): 7. 
Riza, Achmad Kemal. "Contemporary Fatawa of Nahdlatul Ulama Between Observing the Madhhab and Adapting the Context." JOURNAL OF INDONESIAN ISLAM 05, no. 01 (Juni 2011).

Sadlān, Șāliḥ bin Ghānim al-. al-Qawā'id al-Fiqhiyyah al-Kubrā wa mā Tafarra'a 'Anhā. Riyaḍ: Dār al-Balansiyah, 2000.

Saiti, Buerhan, dan Adam Abdullah. "The Legal Maxims of Islamic Law (Excluding Five Leading Legal Maxims) and Their Applications in Islamic Finance," 2016.

. "The Legal Maxims of Islamic Law (Excluding Five Leading Legal Maxims) and Their Applications in Islamic Finance (1)," t.t., 13.

Saputra, Hijrah, Andriansyah Syihabuddin, dan Adhika Prasetya, ed. Himpunan Fatwa Keuangan Syariah Dewan Syariah Nasional MUI. Jakarta: Erlangga, 2014.

Syātịīī, Abū Isḥāq bin Ibrāhīm al-. al-Muwāfaqāt. Beirut - Lebanon: Dar al-Kutub al-'Ilmiyah, 2003.

Warad, Fatḥ̄ Muhammad Abu al-. Atsaru Qāidah al-hājah Tunazzilu Manzilah al-Darūrah fì Isqāti Úqūbah al-Sirqah fì Fiqh alJināi al- Mu-āṣir. Riyaḍ: Markaz al-Tamyīz al-Baḥtsī fī Fiq al-Qaḍāyā al-Mu'āșirah, 2010.

Yasini, Marifatul Haq. Shari'ah Decisions on Financial Matters and the Application of Islamic Legal Maxims (Al-Qawa'id AlKuliyyah): A Comparative Analysis Between the Modern and Classical Applications, 2015.

Zair, Walīd Șalāḥuddīn al-. "Dawābiṭ al-Ḥājah al-Latī Tanzilu Manzilah al-Darurah wa Tatbīqatuha 'ala al-Ijthād alMu'așirah." Majallah Jāmi'ah Dasakus li al-'Ulūm alIqtișādiyyah wa al-Qānūniyyah 26, no. 2 (2010).

Zakariyah, Luqman. "Legal Maxims and Islamic Financial Transactions: A Case Study of Mortgage Contracts and the Dilemma for Muslims in Britain." Arab Law Quarterly 26, no. 3 (1 Januari 2012): 255-85. doi:10.1163/1573025512341240 .

Zuhailī, Muḥammad Muṣțafā al-. al-Qawāid al-Fiqhiyyah wa Tațbìqatuhā fì al-Mdzāhib al-Arbaáh. Vol. 1. Damaskus: Dār al-Fikr, 2009. 